\title{
Postnatal development of the dopaminergic signaling involved in the modulation of intestinal motility in mice
}

\author{
Maria Grazia Zizzo', Giacomo Cavallaro², Michelangelo Auteri', Gaetano Caldara', Ilaria Amodeo², Mariangela Mastropaolo',

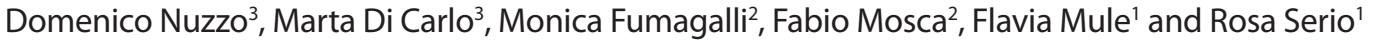

BACKGROUND: Since antidopaminergic drugs are pharmacological agents employed in the management of gastrointestinal motor disorders at all ages, we investigated whether the enteric dopaminergic system may undergo developmental changes after birth.

METHODS: Intestinal mechanical activity was examined in vitro as changes in isometric tension.

RESULTS: In 2-d-old (P2) mice, dopamine induced a contractile effect, decreasing in intensity with age, replaced, at the weaning (day 20), by a relaxant response. Both responses were tetrodotoxin (TTX)-insensitive. In P2, dopaminergic contraction was inhibited by D1-like receptor antagonist and mimicked by D1-like receptor agonist. In 90-d-old (P90) mice, the relaxation was reduced by both D1- and D2-like receptor antagonists, and mimicked by D1- and D2-like receptor agonists. In P2, contraction was antagonized by phospholipase C inhibitor, while in $\mathrm{P} 90$ relaxation was antagonized by adenylyl cyclase inhibitor and potentiated by phospholipase $\mathrm{C}$ inhibitor. The presence of dopamine receptors was assessed by immunofluorescence. Quantitative real-time polymerase chain reaction (qRT-PCR) revealed a significant increase in D1, D2, and D3 receptor expression in proximal intestine with the age.

CONCLUSION: In mouse small intestine, the response to dopamine undergoes developmental changes shifting from contraction to relaxation at weaning, as the consequence of D2-like receptor recruitment and increased expression of D1 receptors.

$\mathbf{P}$ ostnatal development of the gastrointestinal (GI) tract is a dynamic process, characterized by substantial morphological and structural transformations coinciding with functional adaptation to the nutritional changes at weaning (1). The thickness of the circular and the longitudinal muscle layers increases with increasing age. Similarly, the size and densities of the myenteric neurons change according to the increasing gut length and the thickness of the muscle. The longest diameters and the area of the nerve cells decrease from duodenum to distal colon and increase with age of the animal. The differences between duodenum and colon might reflect the different physiological properties of the proximal and distal gut as well as a varying grade of maturity (2). Thereafter, GI functions such as intestinal barrier function or motility continue their maturation and development after birth. Rodents, which are more immature than humans at birth, are good models for understanding the intestinal maturation process occurring in premature infants $(3,4)$. Preterm infants have a reduced intestinal motility, leading to an uncontrolled and excessive bacterial growth. This would expose the intestinal wall to high toxin concentrations, which may trigger local inflammatory responses promoting the onset of various GI diseases. The enteric nervous system, one of the key regulators of GI functions, although in newborns seems to be sufficiently mature to permit oral feeding, appears to undergo morphological and functional changes during development (5-8). Indeed, an early postnatal characterization of the neurochemical coding development and its functional impact on GI functions remains largely unknown.

Among the enteric neurons the dopaminergic subset of neurons is late-developing, arising perinatally (9). Recently, dopamine has been shown to be an endogenous inhibitory modulator of intestinal motility in the mouse GI tract acting via receptors located in the gut (10-12). Dopamine receptors belong to the $\mathrm{G}$ protein-coupled receptors family, initially classified in two main classes, D1-like and D2-like receptors, depending upon opposite action on adenyl cyclase (AC) activity (13). However, molecular biology techniques allowed identifying multiple dopamine receptor subtypes: D1-like receptor subfamily, including D1 and D5 receptors, and D2-like receptor subfamily, comprising D2, D3 and D4 subtypes (13). Moreover, a complex interaction with a variety of intracellular targets other than AC system has been discovered (13). In the central nervous system, various components of the dopaminergic system display distinct and robust changes both in transcript and protein levels during postnatal development, aging, disease or following chronic drug treatment $(14,15)$, but little information is available about possible postnatal changes occurring in the enteric dopaminergic system. Recently, Kasirer et al. (16) reported maturational-related changes in dopamine $\mathrm{D}_{2}$ receptor expression in the rat stomach. 
Antidopaminergic drugs are pharmacological agents employed in the gastrointestinal motor disorder management (17), thus, a better knowledge about the enteric dopaminergic system changes in postnatal life could help to improve therapies for patients with GI motility disorders at different ages.

In this view, our aim was to examine, in vitro, the functionality of the dopaminergic system, as a regulator of intestinal contractility, in neonatal mice compared to the adults.

\section{RESULTS}

\section{Histology and Mechanical Activity in P2 vs. P90 Intestinal Preparations}

It is possible histologically to distinguish the four main intestinal layers in both neonatal (P2) and adult (P90) intestinal preparations (Figure 1). In particular, although the boundaries are less marked in P2 small intestine, the outer longitudinal and inner circular muscle can be identified. The thickness of both muscular layers increases as a function of age leading to an absolute enhancement in mechanical activity and in the contractile and relaxant responses in P90 compared to P2 preparations. Indeed, proximal small intestinal segments from P2 and P90 mice exhibited spontaneous mechanical activity consisting of rhythmic changes in isometric tension with a mean amplitude of $20.5 \pm 1.8 \mathrm{mg}(n=21)$ in $\mathrm{P} 2$ and of $231.6 \pm 19.5 \mathrm{mg}(n=21)$ in P90. However, when normalized to the tissue dry weight, the amplitude of the spontaneous contraction did not differ between the preparations $(P>0.05)$. $10 \mu \mathrm{mol} / \mathrm{l} \mathrm{CCh}$ induced a contractile response with an amplitude of $98.7 \pm 5.2 \mathrm{mg}(n=21)$ and $730.8 \pm 70.3 \mathrm{mg}(n=21)$ in P2 and in adults respectively. Indeed, $1 \mu \mathrm{mol} / \mathrm{l}$ Isoproterenol (Iso) induced a relaxant response with an amplitude of $20.7 \pm 3.2 \mathrm{mg}(n=21)$ and $217.3 \pm 11.3 \mathrm{mg}(n=21)$ in $\mathrm{P} 2$ and in adults respectively. Once more, when normalized to the tissue dry weight, there was no difference in the response to $\mathrm{CCh}$ or to Iso between the preparations $(P>0.05)$.
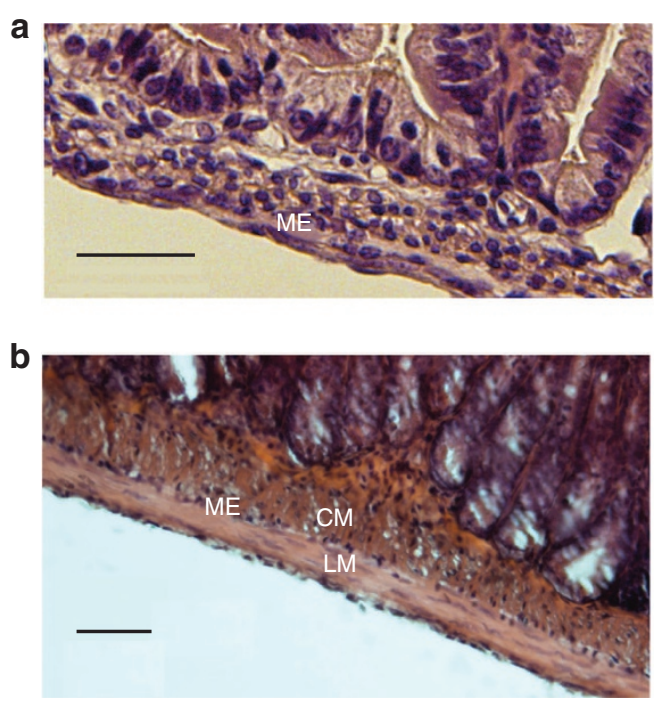

Figure 1. Increased thickness of the muscular layers with age. Thickness of muscularis externa (ME) increases from P2 (a) to P90 (b). CM, circular muscle; LM, longitudinal muscle. Original magnification: $\times 20$. Bar $=25 \mu \mathrm{m}$.
Effects of Dopamine on the Spontaneous Contractile Activity In neonatal preparations (P2), exogenous dopamine induced a contractile effect, which decreased in intensity with age, (Figure 2a,b) being replaced, at weaning (day 20), by a distinct relaxant response, (Figure 2c) increasing in amplitude in adult preparations (Figure 2d).

\section{P2 Preparations and the Contractile Response to Dopamine}

In $\mathrm{P} 2$ preparations, dopamine ( $3 \mu \mathrm{mol} / \mathrm{l}$ to $1 \mathrm{mmol} / \mathrm{l})$ induced a tetrodotoxin (TTX)-insensitive concentration-dependent contractile effect, reaching the maximal amplitude at the dose of $300 \mu \mathrm{mol} / \mathrm{l}$ (absolute increase in muscular tone was about $65 \mathrm{mg})$ with an $\mathrm{EC}_{50}$ of $15.1 \mu \mathrm{mol} / \mathrm{l}(95 \%$ confidence limits (CLs) 3.3-69.0 $\mu \mathrm{mol} / 1, n=12$ ) (Figures $3 \mathrm{a}$ and $4 \mathrm{~b}$ ). A relaxation to dopamine was never observed, even in preparation precontracted with CCh (data not shown). The contractile response to dopamine was significantly antagonized by SCH 23390 $(3 \mu \mathrm{mol} / \mathrm{l})$, a D1-like receptor antagonist $\left(\mathrm{EC}_{50}=193.5 \mu \mathrm{mol} / \mathrm{l}\right.$; 95\% CLs 24.9-150.1 $\mu \mathrm{mol} / 1, n=6$; $P<0.05$ compared to dopamine alone), but it was unaffected by domperidone $(5 \mu \mathrm{mol} / \mathrm{l})$, a D2-like receptor antagonist $\left(\mathrm{EC}_{50}=15.9 \mu \mathrm{mol} / \mathrm{l} ; 95 \%\right.$ CLs 2.9-78.1 $\mu \mathrm{mol} / \mathrm{l}, n=6$ ), suggesting activation of D1 receptors (Figure 3a). SKF 38393 (1-300 $\mu \mathrm{mol} / \mathrm{l})$, a D1-like receptor agonist, mimicked the contractile dopaminergic response, while bromocriptine (1-300 $\mu \mathrm{mol} / \mathrm{l})$, a D2-like receptor agonist, was without effect (Figures $3 \mathrm{~b}$ and $4 \mathrm{a})$ ). The response to SKF 38393 was TTX-insensitive and antagonized by SCH 23390 (Figure 4b). SCH 23390 or domperidone per se had no effects on the spontaneous activity.

\section{P90 Preparations and the Relaxant Response to Dopamine}

In $\mathrm{P} 90$ preparations, dopamine induced a TTX-insensitive dose-dependent relaxation with a maximal amplitude of about $110 \mathrm{mg}$ at a dose of $300 \mu \mathrm{mol} / \mathrm{l}\left(\mathrm{EC}_{50}=6.76 \mu \mathrm{mol} / \mathrm{l}\right.$; a
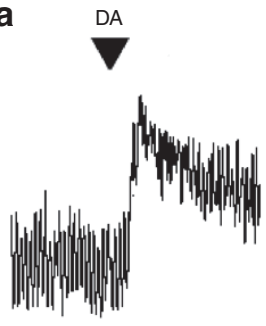

b

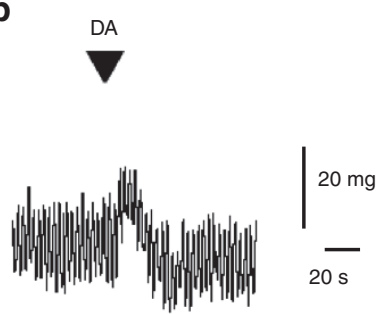

C

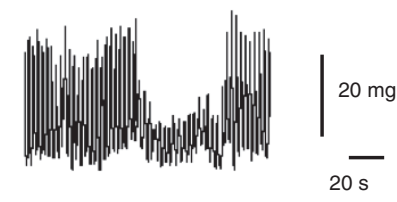

d

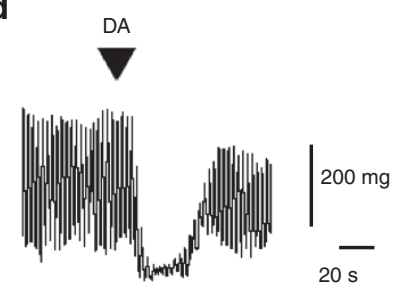

Figure 2. Shift of the mechanical responses to DA in mouse intestinal preparations from contractile to relaxant, between $\mathrm{P} 2$ and $\mathrm{P} 90$. Tracings showing the responses evoked by dopamine in P2 (a), P9 (b), P20 (c), and P90 (d) intestinal preparations. 
P2

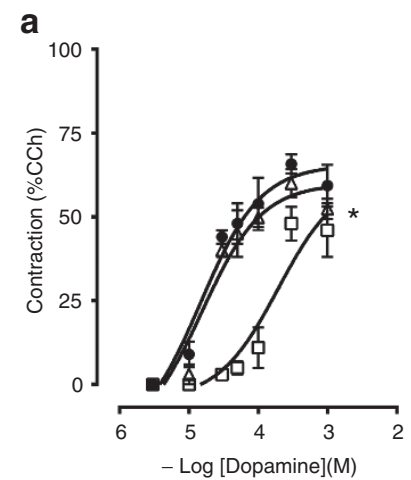

P90

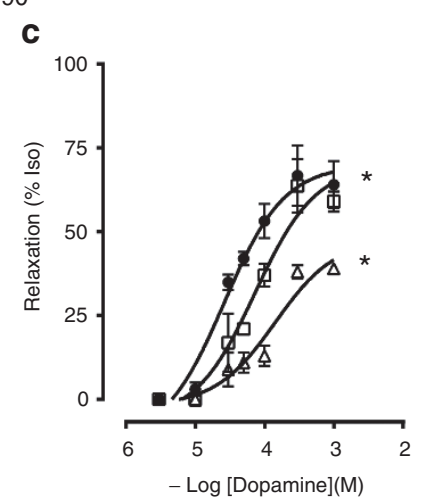

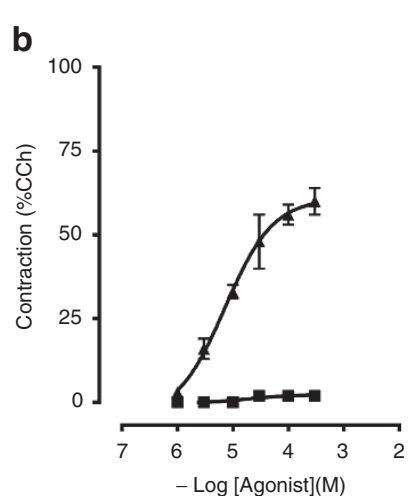

d

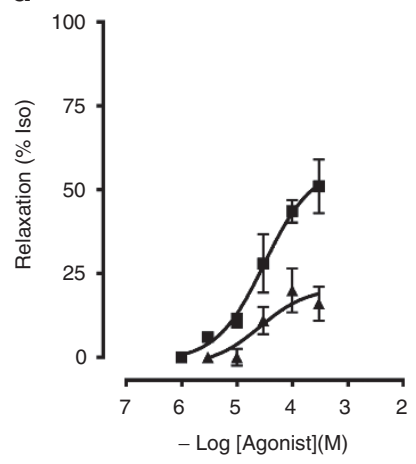

Figure 3. Effects of dopaminergic drugs on P2 and P90 intestinal preparations. Left $(\mathbf{a}, \mathbf{c})$ Concentration-response curves to dopamine ( $3 \mu \mathrm{mol} / \mathrm{l}$ to $1 \mathrm{mmol} / \mathrm{l}$ ) in the absence (control, close circle) or in the presence of SCH 23390, D1-like receptor antagonist $(3 \mu \mathrm{mol} / \mathrm{l}, n=6$ for each age, open square) or domperidone, D2-like receptor antagonist (5 $\mu \mathrm{mol} / \mathrm{l}, n=6$ for each age, open triangle), in P2 or in P90 intestinal preparations. Right (b,d) Concentration-response curves to SKF 38393, D1-like receptor agonist (1-300 $\mu \mathrm{mol} / \mathrm{l}, n=6$ for each age, close triangle) or Bromocriptine, D2-like receptor agonist (1-300 $\mu \mathrm{mol} / \mathrm{l}, n=3$ for each age, close square), in P2 or in P90 intestinal preparations. Data are means \pm SEM. Contractile responses are expressed as percentage of response to $10 \mu \mathrm{mol} / \mathrm{l}$ carbachol (CCh). Relaxant responses are expressed as percentage of the response induced by $1 \mu \mathrm{mol} / \mathrm{I}$ Isoproterenol (Iso). ${ }^{*} P<0.05$ when compared to the control.

95\% CLs 3.5-13.1 $\mu \mathrm{mol} / \mathrm{l}, n=12$; Figures $3 \mathrm{c}$ and 4 d). Contractile effects were never observed in adult preparations. The relaxation effects were markedly inhibited by domperidone $(5 \mu \mathrm{mol} / \mathrm{l})\left(\mathrm{EC}_{50}=142.5 \mu \mathrm{mol} / \mathrm{l} ; 95 \% \mathrm{CLs}\right.$ 34.2-589.8 $\mu \mathrm{mol} / \mathrm{l}, n=6 ; P<0.05$ compared to dopamine alone), indicating an involvement of $\mathrm{D} 2$-like receptors in the response (Figure 3c). Moreover, a rightward shift of the dopamine dose-response curve in the presence of SCH 23390 $(3 \mu \mathrm{mol} / \mathrm{l})\left(\mathrm{EC}_{50}=73.5 \mu \mathrm{mol} / \mathrm{l} ; 95 \%\right.$ CLs $25.2-214.0 \mu \mathrm{mol} / \mathrm{l}$, $n=6 ; P<0.05$ compared to dopamine alone), was also observed, suggesting that D1-like receptor activation also occurs (Figure 3c). SCH $23390(3 \mu \mathrm{mol} / \mathrm{l})$, per se, transiently increased the basal tone of about $200 \mathrm{mg}$ and the amplitude of the spontaneous contractions of about 18\%. Both SKF 38393 $(1-300 \mu \mathrm{mol} / \mathrm{l})$ and bromocriptine $(1-300 \mu \mathrm{mol} / \mathrm{l})$ induced TTX-insensitive relaxant responses, mimicking dopamine effects (Figures 3d and 4d), antagonized by respectively D1and D2-like receptor antagonists (Figure 4d).

D1-Mediated Response in P2 vs. P90 Preparations Undergoes a Shift in Signaling From PLC/IP3 to AC/CAMP Pathways

Since there are no specific D1 or D5 receptor agonists or antagonists, we investigated the downstream signaling cascade activated by SKF 38393, D1-like receptor agonist, considering that D1-like receptor family includes receptors linked either to AC/ cAMP pathway or to PLC/IP ${ }_{3}$ pathway (13).

In P2 preparations, the effects induced by SKF 38393 $(100 \mu \mathrm{mol} / \mathrm{l})$ were significantly antagonized in the presence of U73122 $(1 \mu \mathrm{mol} / \mathrm{l}))$, a PLC inhibitor, but not by pretreatment with $2^{\prime} 3^{\prime}$ dideoxyadenosine (DDA) $(10 \mu \mathrm{mol} / \mathrm{l})$, an AC inhibitor (Figure 5a). In P90 preparations, SKF $38393(100 \mu \mathrm{mol} / \mathrm{l})$ effects were antagonized by DDA $(10 \mu \mathrm{mol} / \mathrm{l})$. Indeed, an increase in the amplitude of the relaxation induced by SKF 38393 was observed in the presence of U73122 $(1 \mu \mathrm{mol} / \mathrm{l})$ (Figure 5b).

\section{The Abundance of D1, as of D2 and D3 Receptors Increase Significantly With Age}

Quantitative real-time PCR was employed to quantify transcripts encoding D1-like receptors (D1 and D5) and D2- like (D2, D3, and D4) as a function of age in P2 vs. P90. Transcripts encoding D1, D2, D3, and D5 receptors were detectable in both preparations (Figure 6). In P2 preparations, (black bars)D5 receptors were more expressed than the other receptors. D1, D2, and D3 receptor expression significantly increased in P90 (white bars) compared to P2 preparations. There was a minor, but not significant, change in D5 receptor expression. As already observed (11), the expression of D4 receptors was not found in the neuromuscular compartment of both intestinal preparations (Figure 6).

\section{Localization of Dopaminergic Receptors}

Immunofluorescence was used to obtain additional evidence for the presence of dopaminergic receptors in the neuromuscular layer of P2 and P90 small intestinal preparations. The labeling for D1, D2, D3, and D5 receptors was detected in both preparations, mainly at the level of the myenteric ganglia (Figure 7a-h).

Note that D1 immunofluorescence was detected as a bright signal in P2 preparations, and with the progress of the age, there was an increase of fluorescence in the neuromuscular layer, both at level of the circular and longitudinal smooth muscle and in the myenteric plexus showing an age-dependent increase (Figure 7a,b). A partial increase with the age of D2 and $\mathrm{D} 3$ receptors is also visible (Figure $7 \mathbf{e}-\mathbf{h}$ ).

\section{DISCUSSION}

In this study, we show that, in mice, the dopaminergic system, controlling intestinal contractility, undergoes developmental changes in the levels of receptors transcripts expression and signaling pathways. In P2 preparations, dopamine induced a contractile response, which markedly decreased with age, shifting to a muscular relaxation at weaning. In postnatal preparations, dopamine seems to activate only D1-like receptors, specifically D5 receptor subtypes, with a net contractile effect. 


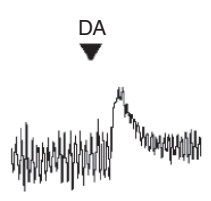

P2 Postnatal preparations

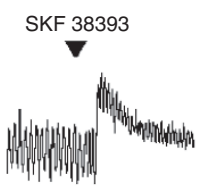

C

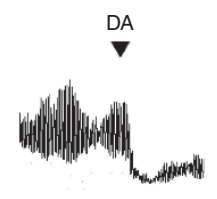

P90 Postnatal preparations

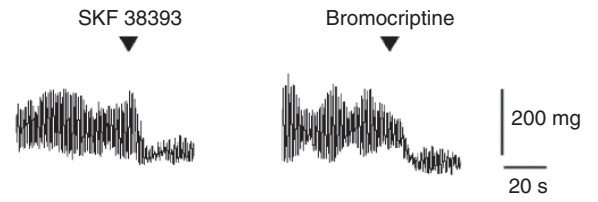

b

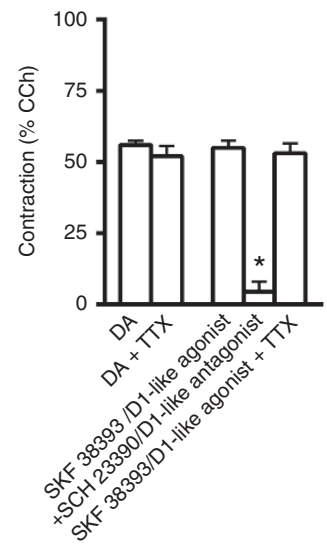

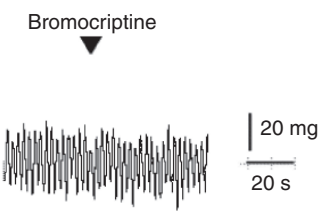

(2)

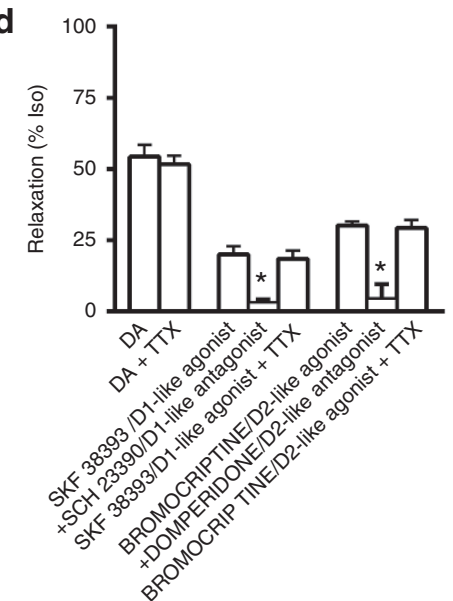

Figure 4. Compared responses to dopaminergic drugs and tetrodotoxin (TTX), the $\mathrm{Na}^{+}$voltage-gated neural channel blocker in $\mathrm{P} 2$ and $\mathrm{P} 90$ postnatal preparations: Left-Original tracings showing the responses to dopamine (100 $\mu \mathrm{mol} / \mathrm{l})$, SKF 38393 D1-like receptor agonist (100 $\mu \mathrm{mol} / \mathrm{l})$, or Bromocriptine D2-like receptor agonist $(100 \mu \mathrm{mol} / \mathrm{l})$, in P2 (A) or in P90 (c) intestinal preparations. Right-Effects of TTX $(1 \mu \mathrm{mol} / \mathrm{l}, n=4)$ or SCH $23390,(3 \mu \mathrm{mol} / \mathrm{l}, n=4)$ or domperidone $(5 \mu \mathrm{mol} / \mathrm{l}, n=4)$. On the response induced by dopamine $(100 \mu \mathrm{mol} / \mathrm{l})$ or SKF $38393(100 \mu \mathrm{mol} / \mathrm{l})$ or Bromocriptine $(100 \mu \mathrm{mol} / \mathrm{l})$ in P2 (b) or in P90 (d) intestinal preparations. Data are means \pm SEM. Contractile responses are expressed as percentage of response to $10 \mu \mathrm{mol} / \mathrm{I} C \mathrm{Ch}$. Relaxant responses are expressed as percentage of the response to $1 \mu \mathrm{mol} / \mathrm{l}$ Iso. ${ }^{*} P<0.05$ when compared to the control.

P2

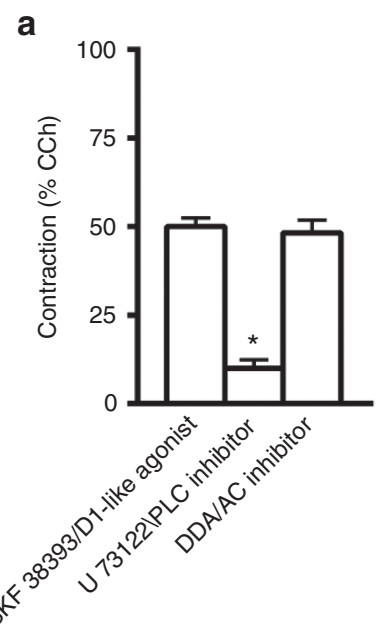

P90

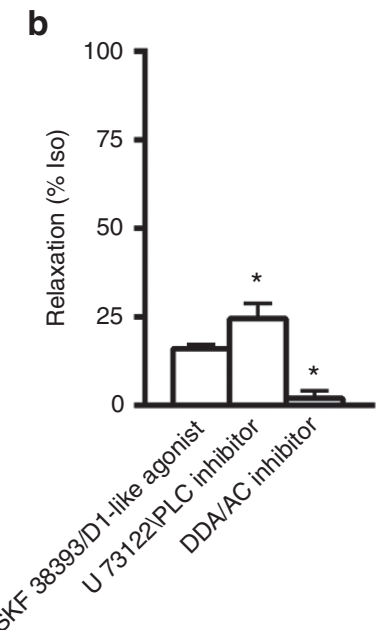

Figure 5. Downstream signaling activated by D1 and D5 receptors. Effects of $\mathrm{U} 73122$ ( $1 \mu \mathrm{mol} / \mathrm{l}, n=7$ each), a PLC inhibitor, or 2' $3^{\prime}$ dideoxyadenosine $(10 \mu \mathrm{mol} / \mathrm{l}, n=7$ each), an AC inhibitor, on the responses induced by SKF 38393, (100 $\mu \mathrm{mol} / \mathrm{l})$, in P2 (a) and in P90 (b) preparations. Data are means \pm SEM. Contractile responses are expressed as percentage of the response to $10 \mu \mathrm{mol} / \mathrm{I} \mathrm{CCh}$. Relaxant responses are expressed as percentage of the response to $1 \mu \mathrm{mol} / \mathrm{l}$ Iso. ${ }^{*} P<0.05$ when compared to the control.

In adult preparations, the relaxant response to dopamine is due to the involvement of D1-like receptors, specifically D1 receptor subtypes, and of D2-like receptors, the latter playing a major role.

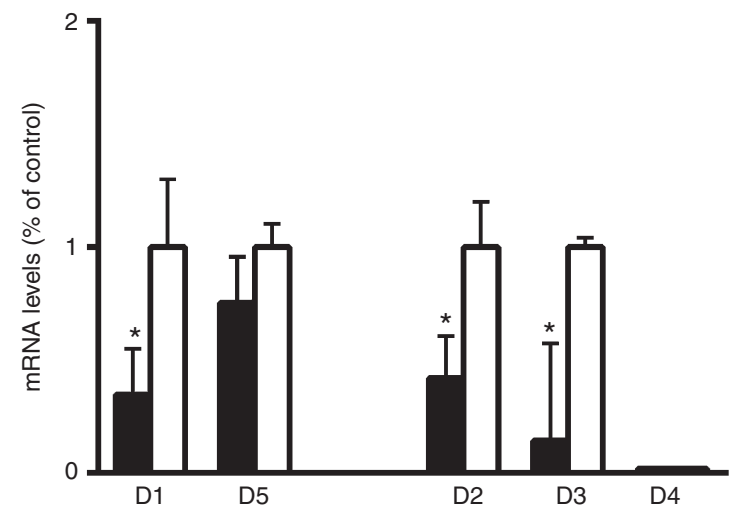

Figure 6. Age-dependent changes of dopamine receptor expression in mouse intestine. Expression levels of dopamine receptor mRNA in intestinal preparations from neonatal ( $\mathrm{P} 2$, black bars) mice and adult ( $\mathrm{P} 90$, white bars) mice, Gene expression was nomalized by glyceraldehyde 3-phosphate dehydrogenase. D4 receptor expression was not detected because the RNA was extracted from the neuromuscular intestinal part of the gut excluding the mucosa, where in the latter only the D4 receptors are expressed.

In the gut, various gastrointestinal functions continue their maturation and development after birth (18). Recent studies reported that in mouse duodenum, differently from colon, neurally mediated contraction complexes were present just prior to the birth, but both the threshold required to induce propagating complexes and the mechanisms controlling intestinal motility change during the first postnatal week (19). Dopamine, released by enteric nerves, or by non-neural 


\section{Articles $\mid$ Zizzo et al.}
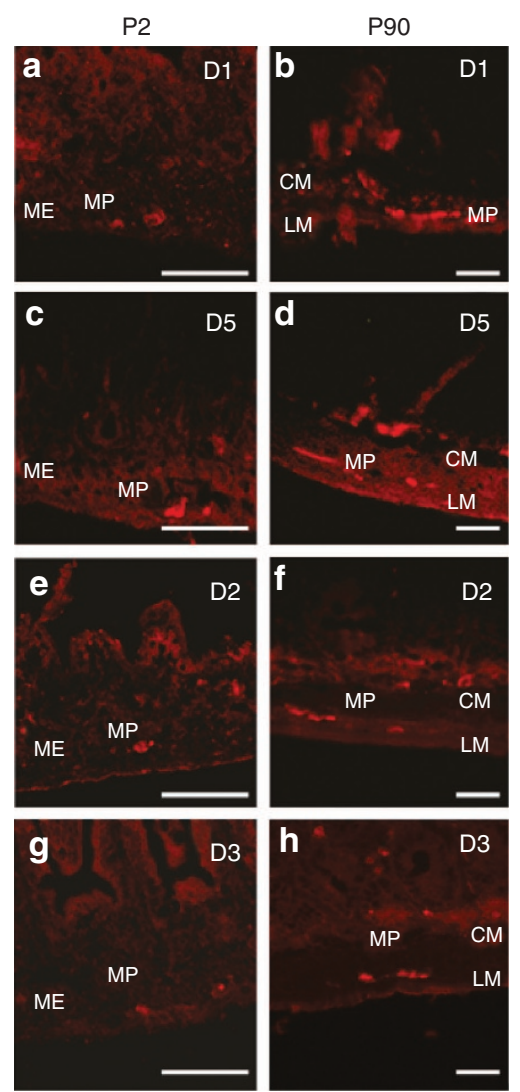

Figure 7. Dopamine receptor immunofluorescence staining in $\mathrm{P} 2$ and P90 intestinal preparations. P2 (left) and P90 (right) intestinal preparations were labeled with antibody (red) for D1 (a, b), D5 (c, d), D2 (e, f), and D3 $(\mathbf{g}, \mathbf{h})$ receptors. CM, circular muscle; LM, longitudinal muscle; $\mathrm{ME}$, muscolaris externa; MP, myenteric plexus. Scale bars: $=25 \mu \mathrm{m}$.

cells, as epithelial or immune cells, usually acts as an inhibitory modulator of intestinal motility via activation of D1-like and D2-like receptors (10-12,20-22). Due to tissue- and species-specific differences, the comprehension of the receptors involved and their related mechanisms is complicated. In this study, we investigated the dopaminergic system role in the control of intestinal motility in neonatal vs. adult preparations. Li et al. (11) have showed that dopaminergic neurons arise perinatally and transcripts for all dopaminergic receptors were detected in mouse intestine at all ages. Our results show that the dopaminergic system undertakes a development and maturation process after birth, leading to postnatal changes in the pattern of receptor functionality.

The dopaminergic system in the proximal intestine is functional at birth, being that dopaminergic drugs are able to induce a response by the second day after birth. Specifically, in P2 intestinal preparations, we observed a contractile response to dopamine, while a frank muscular relaxation was detected in the adult P90 preparations. Indeed, different receptor subtypes are involved in the observed responses. In P2 preparations, dopaminergic contraction is mediated by D1-like receptor activation, as suggested by the sensitivity of the response to the selective D1-like receptor antagonist, SCH 23390, and by the observation that the dopaminergic response was mimicked by SKF 38393, a D1-like receptor agonist. Moreover, in this early postnatal period, the effects of dopamine were unaffected by D2-like receptor antagonist or mimicked by the D2-like agonist, excluding an involvement of these receptors in the response. Instead, in adult preparations, dopamine caused a reliable muscular relaxation, via both D1-like and D2-like receptors, with D2-like receptors playing a major role. Dopaminergic inhibitory effects were markedly reduced by domperidone, D2-like receptor antagonist, and to a lesser extent by SCH 23390, the D1-like receptor antagonist. Both SKF 38393, the D2-like agonist and bromocriptine, a D2-like receptor agonist, caused muscular relaxation with bromocriptine being more effective. Although immunofluorescence analysis of dopaminergic receptor is indicate a major expression in the myenteric ganglia, the functional involvement of dopaminergic receptors located postsynaptically on intermediary enteric neurons may be unlikely since the contraction and relaxation induced by exogenous dopamine or its agonists were not modified by TTX.

Intriguingly, the contractile response to dopamine, in P2 preparations, markedly decreases with age, shifting to a muscular relaxation at weaning. Indeed, in rat duodenum, relaxant responses to some inhibitory mediators are not obvious before postnatal days $12-14(23,24)$. Our finding might be explained assuming that, with the progress of growth, the basal tone becomes higher and reaches a critical level, where a relaxant dopaminergic response would be evident, on about day 20 . However, such a hypothesis can be discarded since P2 preparations were able to relax in response to isoproterenol, and dopamine was unable to induce relaxant effect even in preparation precontracted with CCh.

The change in the pattern of the dopaminergic response seems to rely on the different receptor subtypes recruited at the different ages. Transcripts for all dopamine receptor subtypes, except for D4 receptors, have been detected in the neuromuscular compartment of mouse small intestinal wall at neonatal age, as already reported (24) and as showed in this paper. However, in $\mathrm{P} 2$ preparations, dopamine appears to be able to activate only D1-like receptors with a net contractile effect, implying that D2-like receptors are not functionally coupled at this early age. In adult preparations, the dopaminergic relaxation appears to be due to the switch of D1-like receptors from mediating contraction to relaxation and to the involvement of inhibitory D2-like receptors. A major finding of this study is that, with the progress of the age, D1-like receptor activation leads to inhibitory responses instead of excitatory effects. Actually, in mouse intestine, Giaroni et al. (25) reported that P2Y1 receptor-mediated contractions, prominent from day 3 , decreased with age, disappeared at weaning. This switch of the effects seems to be related to a later localization of the P2Y1 receptors from myenteric neurons to smooth muscle cells (25). D1-like receptors is an heterogeneous family including D1 and D5 receptor subtypes, sharing $80 \%$ sequence homology (13). In our experiments, while D5 receptor localization seems not be modified with the age, being mainly expressed in the myenteric plexus, D1 receptor immunofluorescence increases in both myenteric plexus and in the 
muscular layers with the age. Therefore, developmental changes both in the levels and pattern of D1-like receptor expression could lead to the switch of D1-like receptor effect. Recent studies indicate a transcriptional, post-transcriptional or post-translational regulation of the expression of D1 receptors during neuronal differentiation (26,27). D1 and D5 receptor subtypes may be coupled to different downstream signaling. It appears that D1 receptors are AC-coupled, while D5 receptors are PLC-coupled $(13,28)$. We showed that the contractile response via D1-like receptors in neonatal preparation was inhibited by PLC blocker, while the relaxation observed in adult preparation was decreased by AC blocker, and enhanced by PLC blocker. Therefore, we can suggest that dopaminergic contractile effect in postnatal period is mediated by PLC/coupled-D5 receptors, while in adult preparation the $\mathrm{D} 1$-like mediated response is mainly mediated by $\mathrm{AC} /$ coupled D1 receptors. In support of such a hypothesis, we demonstrated that, although D1 and D5 transcripts and receptors are both expressed in the small intestine at all ages, interestingly, D1 expression appears to be developmentally regulated showing an age-dependent increase, while D5 expression remained substantially stable. Therefore, we suggest that the net effect of D1-like receptor activation is the sum of contraction and relaxation. In neonatal preparation, the D1-like-mediated contractile response could be explained assuming a preponderance of PLC/coupledD5 receptors, while in adult preparation, the increased expression of the AC/coupled-D1 receptors would make relaxation the dominating response. In addition, in adults there is also a recruitment of inhibitory D2-like receptors, which potentiate the dopaminergic relaxant response. The observed developmental-related changes in D2 and D3 receptor expression may account for their involvement in adults. Accordingly, a maturational-dependent increase in dopamine D2 receptor expression in the rat stomach has been recently reported (16).

Although the exact physiological importance of this process is still unknown and further investigations are required, the developmental changes in dopamine functional pattern could play an important role in the modification of small intestine motility occurring at weaning, to allow the adaptation of GI motor pattern to adult feeding. The consequent slowing down of the intestinal peristalsis may facilitate the interaction between the luminal content and the intestinal wall, improving the digestive and absorptive processes of complex sugars.

In conclusion, the receptor changes in the enteric nervous system may represent the adaptive response of the intestine to environmental stimuli to ensure the acquisition of a mature pattern of gut motility. Thus, since the biologic systems constantly evolve from birth to adulthood, our results on the developmental changes of the response to dopamine on intestinal motility may help to improve the knowledge about the therapeutic value of antidopaminergic drugs as prokinetic agents early in life.

\section{METHODS}

\section{Animals and Preparations}

Experiments were authorized by the Ministero della Sanità (Rome, Italy), and comply with Italian and European Union regulations. C57BL/6SnJ mice (Charles River, Calco LC, Italia) were individually housed in cages on a 12:12-h light-dark cycle with free access to food and water. Time-pregnancies were induced by overnight mating. Day of birth was considered as postnatal day (P0). Mothers and their pups (six to eight pups/litters) were kept in the same conditions during the whole experiments. Pups were euthanized (isoflurane inhalation followed by cervical dislocation) at 2, 9, 20, and 90 (adult) days.

The abdomen was immediately opened and segments of proximal small intestine (about $10 \mathrm{~mm}$ in length), just distal to the pylorus, were carefully dissected and the contents gently flushed out with Krebs solution (mmol/l: $\mathrm{NaCl} 119 ; \mathrm{KCl} 4.5 ; \mathrm{MgSO}_{4} 2.5 ; \mathrm{NaHCO}_{3} 25$; $\mathrm{KH}_{2} \mathrm{PO}_{4} 1.2, \mathrm{CaCl}_{2} 2.5$, glucose 11.1). Then, segments were opportunely processed for mechanical, histological, or molecular studies.

\section{Recording of Mechanical Activity}

Segments were suspended in vertical organ baths containing oxygenated $\left(95 \% \mathrm{O}_{2}\right.$ and $\left.5 \% \mathrm{CO}_{2}\right)$ Krebs solution maintained to $37^{\circ} \mathrm{C}$. The distal end of each segment was tied to an organ holder and the proximal end was secured with a silk thread to an isometric force transducer (FORT 10, Ugo Basile, Comerio VA, Italy). Preparations were stretched with a preload of $50-200 \mathrm{mg}$ of tension (depending on the age of the mouse) and allowed to equilibrate for at least $30 \mathrm{~min}$. Mechanical activity was digitized on an A/D converter, visualized, recorded, and analyzed on a personal computer using the PowerLab/400 system (Ugo Basile).

At the beginning of each experiment, preparations were challenged either with $10 \mu \mathrm{mol} / \mathrm{l}$ Carbachol (CCh) or with $1 \mu \mathrm{mol} / \mathrm{l}$ Iso for $2 \mathrm{~min}$ until reproducible responses were obtained. In intestinal preparations, from neonatal (P2) and adult (P90) mice concentration-dependent

Table 1. Primer sequences for quantitative real-time polymerase chain reaction

\begin{tabular}{|c|c|c|c|}
\hline Target genes & Primer sequences & RealTime program & $\begin{array}{c}\text { Accession } \\
\text { number } \\
\text { GenBank }\end{array}$ \\
\hline D1 & $\begin{array}{l}\text { Forward: 5'-GTA GCC ATT ATG ATC GTC AC-3'; } \\
\text { Reverse: 5'-GAT CAC AGA CAG TGT CTT CAG-3' }\end{array}$ & $\begin{array}{l}\text { Denaturation } 94^{\circ} \mathrm{C}+\left(94^{\circ} \mathrm{C} 30^{\prime \prime} 55^{\circ} \mathrm{C}\right. \\
\left.45^{\prime \prime} 60^{\circ} \mathrm{C} 30^{\prime \prime}\right) \times 40+\text { Elongation } 5^{\prime}\end{array}$ & AK044723 \\
\hline D2 & $\begin{array}{l}\text { Forward: 5'-GCA GCC GAG CTTTCA GAG CC-3'; } \\
\text { Reverse: 5'-GGG ATG TTG CAG TCA CAG TG-3' }\end{array}$ & $\begin{array}{c}\text { Denaturation } 94^{\circ} \mathrm{C}+\left(94^{\circ} \mathrm{C} 30^{\prime \prime} 60^{\circ} \mathrm{C}\right. \\
\left.45^{\prime \prime} 60^{\circ} \mathrm{C} 30^{\prime \prime}\right) \times 40+\text { Elongation } 5^{\prime}\end{array}$ & X55674 \\
\hline D4 & $\begin{array}{l}\text { Forward: 5'-CAC CAA CTA CTT CAT CGT GA-3'; } \\
\text { Reverse: 5'-AAG GAG CAG ACG GAC GAG TA-3' }\end{array}$ & $\begin{array}{c}\text { Denaturation } 94^{\circ} \mathrm{C}+\left(94^{\circ} \mathrm{C} 30^{\prime \prime} 58^{\circ} \mathrm{C}\right. \\
\left.45^{\prime \prime} 60^{\circ} \mathrm{C} 30^{\prime \prime}\right) \times 40+\text { Elongation } 5^{\prime}\end{array}$ & U19880 \\
\hline D5 & $\begin{array}{l}\text { Forward: 5'-CTA CGA GCG CAA GAT GAC C-3'; } \\
\text { Reverse: 5'-CTCTGA GCA TGC TCA GCT G-3'3' }\end{array}$ & $\begin{array}{c}\text { Denaturation } 94^{\circ} \mathrm{C}+\left(94^{\circ} \mathrm{C} 30^{\prime \prime} 61^{\circ} \mathrm{C}\right. \\
\left.45^{\prime \prime} 60^{\circ} \mathrm{C} 30^{\prime \prime}\right) \times 40+\text { Elongation } 5^{\prime}\end{array}$ & AK045456 \\
\hline $\begin{array}{l}\text { Mouse glyceraldehyde 3-phosphate } \\
\text { dehydrogenase }\end{array}$ & $\begin{array}{l}\text { Forward: 5'-AGG CCG GTG CTG AGT ATG TC-3'; } \\
\text { Reverse: 5'-TGC CTG CTT CAC CAC CTT CT-3'3 }\end{array}$ & $\begin{array}{c}\text { Denaturation } 94^{\circ} \mathrm{C}+\left(94^{\circ} \mathrm{C} 30^{\prime \prime} 54^{\circ} \mathrm{C}\right. \\
\left.45^{\prime \prime} 60^{\circ} \mathrm{C} 30^{\prime \prime}\right) \times 40+\text { Elongation } 5^{\prime}\end{array}$ & M32599 \\
\hline
\end{tabular}


curves were constructed by noncumulative addition of dopamine before and after treatment with selective dopamine receptor antagonists. Moreover, selective D1-like or D2-like receptor agonists, SKF 38393 and bromocriptine respectively, were tested in both preparations. Agonists were applied for $3 \mathrm{~min}$ at 20 -min intervals. Time control experiments showed that a second curve to the agonists was reproducible.

Moreover, in both preparations, a submaximal dose of dopamine or of dopamine agonists was tested in the presence of tetrodotoxin, $\mathrm{a} \mathrm{Na}^{+}$ voltage-gated neural channel blocker. In another set of experiment, a submaximal dose of SKF $38393(100 \mu \mathrm{mol} / \mathrm{l})$, D1 receptors agonist, was tested in the presence of U-73122 (1 $\mu \mathrm{mol} / \mathrm{l})(29)$, a phospholipase C (PLC) inhibitor, or, an AC inhibitor DDA (10 $\mu \mathrm{mol} / \mathrm{l})(10)$.

Each preparation was tested with a single agonist/antagonist, except when otherwise stated. Concentrations of the drugs used were determined from literature. All the antagonists were maintained in contact with the tissue for at least $30 \mathrm{~min}$ before testing the agonists.

\section{Drugs}

Drugs used were: carbamylcholine chloride (carbachol, CCh), DDA, domperidone, dopamine, 7-chloro-8-hydroxy-3-methyl1-phenyl-2,3,4,5-tetrahydro-1H-3-benzazepine hydrochloride ( $\mathrm{SCH}$ 23390), isoproterenol, TTX, \{1-[6((17 $\beta$-3-Methoxyestra- $1,3,5$ (10)-trien-17-yl)amino)hexyl]-1H-pyrrole-2,5-dione $\quad$ (U-73122), (Sigma-Aldrich, St. Louis,US). Bromocriptine mesylate, $( \pm)$-1-Phenyl2,3,4,5-tetrahydro-( $1 H$ )-3-benzazepine-7,8-diol hydrobromide (SKF 38393) (Tocris-Bioscience, Bristol, UK). Bromocriptine, DDA, domperidone, and U-73122 were dissolved in dimethyl sulfoxide; all the other drugs were dissolved in distilled water. Fresh solutions were prepared on the day of the experiment by diluting the stock solutions in Krebs. Control experiments showed that the maximal final concentration of dimethyl sulfoxide in the organ bath did not affect the intestinal segment contractility.

\section{Histological Analysis}

Small intestine specimens from P2 and P90 mice were cut to obtain full thickness strips and fixed overnight in $10 \%$ neutral formalin (Sigma-Aldrich) at room temperature before dehydration in alcohol solutions in ascending order for paraffin embedding. For morphometric analyses, paraffin standard 4 - $\mu$ m-thick sections were processed and stained with hematoxylin and eosin (Bio-Optica Milano, Italy) and then examined under a light microscope Olympus BX50 microscope (Olympus Optical, Tokyo, Japan).

\section{qRT-PCR}

qRT-PCR was used to quantify messenger RNA encoding dopamine D1- and D2 -like receptors in the small intestine. The expression of dopamine receptors was normalized to that of glyceraldehyde 3-phosphate dehydrogenase, a housekeeping gene that is not subject to regulation. Total RNA was extracted from whole thickness small intestinal preparation devoid of mucosa layer from P2 and adult mice using RNeasy lipid tissue mini kit (Qiagen, Valencia, CA). Two nanograms of RNA were used to synthesize the first strand cDNA using RT First-Strand kit (Qiagen,). Synthesized cDNAs were amplified using SYBR Premix Ex Taq II (TaKaRa Bio, Foster City, CA) and StepOne Real-Time instrument (Applied Biosystems, Foster City, CA). Gene expression was performed, in triplicate, using specific primers and amplification conditions listed in Table 1 . On the basis of the $C_{\mathrm{t}}$ value (threshold cycle-the number of reaction cycles after which fluorescence exceeds the defined threshold) of the examined gene and of the internal control gene, the relative expression level of RNA was calculated according to the $2^{\Delta \Delta \mathrm{Ct}}$ approximation method.

\section{Immunofluorescence Imaging}

Immunofluorescence was performed on P2 and P90 intestinal preparations embedded in paraffin and sectioned $(5 \mu \mathrm{m})$ using a microtome. Sections were mounted on glass microscope slides coated in poly-Llysine and paraffinized. Fixed tissues were permeabilized with $0.2 \%$ Triton-X100 in phosphate-buffered saline (PBS) for $20 \mathrm{~min}$ and blocked in $2 \%$ bovine serum albumin, $0.2 \%$ Triton-X100 in PBS for $20 \mathrm{~min}$. Sections were incubated with anti-D1DR (Santa Cruz Biotechnology, Santa Cruz, CA, 1:50), anti-D2DR (Santa Cruz Biotechnology, 1:50), anti-D3DR (EMD Millipore, Billerica, MA, 1:50), anti-D5DR (Santa Cruz Biotechnology, 1:50), at $4{ }^{\circ} \mathrm{C}$ overnight. After washing in PBS the slides were incubated with anti-mouse or anti-goat or anti-rabbit Cy3-conjugated secondary antibodies (Molecular Probes, USA). The samples were analyzed by using a DHL fluorescent microscope (Leica Microsystems, Heidelberg, Germany) at a magnification of $20 \times$.

\section{Statistical Analysis}

All data are presented as means \pm SEM: " $n$ " indicates the number of animal preparations. The amplitude of contractile responses is reported as a percentage of response to $10 \mu \mathrm{mol} / \mathrm{l} \mathrm{CCh}$, while the amplitude of the relaxant responses as a percentage of the response to $1 \mu \mathrm{mol} / \mathrm{l}$ Iso. Dopamine responses were fitted to sigmoid curves (Prism 5.0, Graph-PAD, San Diego, CA) and $\mathrm{EC}_{50}$ values with $95 \%$ CLs were determined. Statistically significant differences were calculated by Student's $t$-test or by means of analysis of variance, followed by Bonferroni's test, when appropriate. A probability value of less than 0.05 was regarded as significant.

\section{STATEMENT OF FINANCIAL SUPPORT}

This work was supported by a grant (FFR 1012-13) from Ministero dell'Università e della Ricerca Scientifica and in part by the CNR project "FaRaBio di Qualità" from Ministero dell'Economia e Finanze, Italy.

Disclosure: The authors declare that there is no conflict of interest that could be perceived as prejudicing the impartiality of the research reported.

\section{REFERENCES}

1. Patel MS, Srinivasan M. Metabolic programming due to alterations in nutrition in the immediate postnatal period. J Nutr 2010;140:658-61.

2. Schäfer KH, Hänsgen A, Mestres P. Morphological changes of the myenteric plexus during early postnatal development of the rat. Anat Rec 1999;256:20-8.

3. Berseth CL. Gastrointestinal motility in the neonate. Clin Perinatol 1996;23:179-90.

4. Drozdowski LA, Clandinin T, Thomson AB. Ontogeny, growth and development of the small intestine: Understanding pediatric gastroenterology. World J Gastroenterol 2010;16:787-99.

5. Gershon MD. Developmental determinants of the independence and complexity of the enteric nervous system. Trends Neurosci 2010;33:446-56.

6. Hao MM, Young HM. Development of enteric neuron diversity. J Cell Mol Med 2009;13:1193-210.

7. de Vries P, Soret R, Suply E, Heloury Y, Neunlist M. Postnatal development of myenteric neurochemical phenotype and impact on neuromuscular transmission in the rat colon. Am J Physiol Gastrointest Liver Physiol 2010;299:G539-47.

8. Foong JP, Nguyen TV, Furness JB, Bornstein JC, Young HM. Myenteric neurons of the mouse small intestine undergo significant electrophysiological and morphological changes during postnatal development. J Physiol 2012;590:2375-90.

9. Chalazonitis A, Tang AA, Shang Y, et al. Homeodomain interacting protein kinase 2 regulates postnatal development of enteric dopaminergic neurons and glia via BMP signaling. J Neurosci 2011;31:13746-57.

10. Zizzo MG, Mulè F, Mastropaolo M, Serio R. D1 receptors play a major role in the dopamine modulation of mouse ileum contractility. Pharmacol Res 2010;61:371-8.

11. Li ZS, Schmauss C, Cuenca A, Ratcliffe E, Gershon MD. Physiological modulation of intestinal motility by enteric dopaminergic neurons and the D2 receptor: analysis of dopamine receptor expression, location, development, and function in wild-type and knock-out mice. J Neurosci 2006;26:2798-807.

12. Walker JK, Gainetdinov RR, Mangel AW, Caron MG, Shetzline MA. Mice lacking the dopamine transporter display altered regulation of distal colonic motility. Am J Physiol Gastrointest Liver Physiol 2000;279:G311-8.

13. Beaulieu JM, Gainetdinov RR. The physiology, signaling, and pharmacology of dopamine receptors. Pharmacol Rev 2011;63:182-217.

14. Hurley MJ, Mash DC, Jenner P. Dopamine D(1) receptor expression in human basal ganglia and changes in Parkinson's disease. Brain Res Mol Brain Res 2001;87:271-9.

15. Jung $A B$, Bennett JP Jr. Development of striatal dopaminergic function. I. Pre- and postnatal development of mRNAs and binding sites for striatal D1 (D1a) and D2 (D2a) receptors. Brain Res Dev Brain Res 1996;94:109-20. 
16. Kasirer MY, Welsh C, Pan J, Shifrin Y, Belik J. Metoclopramide does not increase gastric muscle contractility in newborn rats. Am J Physiol Gastrointest Liver Physiol 2014;306:G439-44.

17. Tonini M, Cipollina L, Poluzzi E, Crema F, Corazza GR, De Ponti F. Review article: clinical implications of enteric and central D2 receptor blockade by antidopaminergic gastrointestinal prokinetics. Aliment Pharmacol Ther 2004;19:379-90.

18. Gershon MD. The play is still being written on opening day: postnatal maturation of enteric neurons may provide an opening for early life mischief. J Physiol 2012;590:2185-6.

19. Roberts RR, Ellis M, Gwynne RM, et al. The first intestinal motility patterns in fetal mice are not mediated by neurons or interstitial cells of Cajal. J Physiol 2010;588(Pt 7):1153-69.

20. Dawirs RR, Teuchert-Noodt G, Kampen WU. Demonstration of dopamine-immunoreactive cells in the gastrointestinal tract of gerbils (Meriones unguiculatus). J Histochem Cytochem 1992;40:1197-201.

21. Eisenhofer G, Aneman A, Friberg P, et al. Substantial production of dopamine in the human gastrointestinal tract. J Clin Endocrinol Metab 1997;82:3864-71.

22. Kirschstein T, Dammann F, Klostermann J, et al. Dopamine induces contraction in the proximal, but relaxation in the distal rat isolated small intestine. Neurosci Lett 2009;465:21-6.
23. Furukawa K, Nomoto T. Postnatal changes in response to adenosine and adenine nucleotides in rat duodenum. Br J Pharmacol 1989;97: 1111-8.

24. Miyazaki H, Ohga A, Saito K. Development of motor response to intramural nerve stimulation and to drugs in rat small intestine. Br J Pharmacol 1982;76:531-40.

25. Giaroni C, Knight GE, Zanetti E, et al. Postnatal development of P2 receptors in the murine gastrointestinal tract. Neuropharmacology 2006;50:690-704.

26. Tobón KE, Chang D, Kuzhikandathil EV. MicroRNA 142-3p mediates post-transcriptional regulation of D1 dopamine receptor expression. PLoS One 2012;7:e49288.

27. Pasuit JB, Li Z, Kuzhikandathil EV. Multi-modal regulation of endogenous D1 dopamine receptor expression and function in the CAD catecholaminergic cell line. J Neurochem 2004;89:1508-19.

28. Sahu A, Tyeryar KR, Vongtau HO, Sibley DR, Undieh AS. D5 dopamine receptors are required for dopaminergic activation of phospholipase C. Mol Pharmacol 2009;75:447-53.

29. Zizzo MG, Mastropaolo M, Grählert J, Mulè F, Serio R. Pharmacological characterization of uracil nucleotide-preferring P2Y receptors modulating intestinal motility: a study on mouse ileum. Purinergic Signal 2012;8:275-85. 